\title{
'New speakers' and language policy research: thematic and theoretical contributions to the field
}

\author{
Jeroen Darquennes ${ }^{1}\left[\right.$ ] Josep Soler ${ }^{2}[$
}

Received: 2 November 2017 / Accepted: 14 December 2018 / Published online: 17 January 2019

(c) The Author(s) 2019

\begin{abstract}
In this article, we reflect on the extent to which 'new speaker' research feeds into recent theoretical discussions in language policy scholarship, especially in connection to the discursive and ethnographically oriented perspectives which of late have become increasingly prominent. We begin with a brief overview of the "new speaker' concept, its theoretical and empirical origins, and then we situate the discussions on 'new speakers' against the background of traditional language policy research. Thereafter the bulk of the article is dedicated to developing two main arguments: first, we provide an overview of the language policy themes that are already present in 'new speaker' research; and secondly, we elaborate on how 'new speaker' studies can contribute to current discussions in the field of language policy. We conclude with a short overview of future research directions that, in our view, can strengthen the link and the mutual benefits of the connection between 'new speaker' and language policy scholarship.
\end{abstract}

Keywords 'New speakers' · Language policy · Ethnography of language policy · Minority languages

\section{Introduction}

In the past two decades, sociolinguistics has shown a growing interest in engaging theoretically and methodologically with the complexity of multilingualism. In order to grasp this complexity in a refreshing way, new concepts and categories have come to complement and/or overtly challenge labels and categories dating back to the

Josep Soler

josep.soler@english.su.se

Jeroen Darquennes

jeroen.darquennes@unamur.be

1 Groupe de Recherche sur le Plutilinguisme (Plurio-LL), Namur Institute of Language, Text and Transmediality, Université de Namur, Rue de Bruxelles 61, 5000 Namur, Belgium

2 Department of English (Room E806), Stockholm University, 10691 Stockholm, Sweden 
early days of sociolinguistics. The 'new speaker' concept is to be understood against this background (e.g. O'Rourke et al. 2015; see also the introduction to this volume). In addition, ideas on existing concepts and the breadth of existing research strands have been further revised and developed. A case in point is language policy research which recently and in contrast to much of the earlier literature on the subject has come to illuminate the multilayered and polyphonic nature of language policy processes (Pérez-Milans and Tollefson 2018).

In this paper, we reflect on the extent to which 'new speaker' research feeds into this remodeled approach to language policy, especially in connection to more discursive and ethnographically oriented perspectives which of late have become increasingly prominent (e.g. Barakos and Unger 2016; Hornberger and Johnson 2007; Johnson 2013). 'New speakers' from all different contexts so far investigated (minority languages, migrant and transnational settings) pose relevant questions in terms of how language is governed, regimented, and policed (O'Rourke and Pujolar 2013). Of particular interest to us is to reflect on how the 'new speaker' concept informs language policy scholarship and vice versa. The overall aim of the paper, therefore, is to examine the place of 'new speaker' research in language policy scholarship, on the one hand, and the place of language policy research in 'new speaker' studies, on the other hand. With this in mind, we elaborate on what language policy can contribute to theoretical discussions on 'new speakers', and what 'new speaker' research can add to current scholarly discussions on language policy and its ontological and epistemological status.

We approach these issues informed by research on regional and minority language communities. The language policy angle on 'new speakers' in such communities is justified. Most of the research conducted under this umbrella term starts from the idea that in contexts of language revitalization processes, 'new speakers' have actually been the outcome of language policy initiatives by acting governments and institutions. However, until recently, their impact on the actual linguistic community has not been thoroughly looked at. Before moving on to more details concerning the interplay between language policy research and research on 'new speaker', it is worth unpacking, even if just briefly, the meaning(s) attached to the 'new speaker' label and the scholarly context within which the label has emerged.

\section{The emergence of the 'new speaker' label}

Over the past years, a number of attempts have been made to enliven the discussion of the concept 'autochthonous language minority' (e.g. May 2001; Rindler Schjerve 2006: 115-118; Darquennes 2014). The emergence of the 'new speaker' concept as used in Galician sociolinguistics (O'Rourke and Ramallo 2013) contributes in a fruitful way to this discussion. Capturing the active users of a minority language that did not acquire that language as a native language the 'new speaker' concept especially helps to highlight the diversity that characterizes such minorities. More specifically, it helps to shed light on the variation inherent to criteria such as language, lineage, self-categorization and social organization that are traditionally used to define a social group as an autochthonous language minority (Allardt 1992). 
The starting point for O'Rourke et al. (2015) when highlighting the added value of the 'new speaker' concept is the weight that has traditionally been put on the native speaker in literature on autochthonous language minorities (e.g. Davies 2003; Doerr 2009). In very broad terms, the native speakers put forward in much of the literature on such minorities are speakers who-following the example of their ancestors-grew up with the minority language, rather strongly identify with that language and the related culture, continue to use it wherever and whenever they can, and try to secure its intergenerational transmission under sometimes very difficult conditions through supporting forms of social organization that help to promote the use of the minority language especially in the home-neighbourhood-community nexus which-following Fishman (1991) as well as the UNESCO's Atlas of the Worlds' Languages in Danger (Moseley 2010) — is considered to be vital for the minority language's intergenerational survival.

The existence of speakers with profiles that diverge from the native speakers' profile as far as the inheritance, acquisition, use and active promotion of the minority language is concerned is everything but denied in literature that was published in the second half of the 20th century. However, such other speakers and the minority language varieties that are used by them are only dealt with at the margins. In retrospect, the literature in which attention is paid to different profiles of minority language speakers (Gal 1979), the use and the role of less purist varieties of minority languages in language maintenance and revitalization strategies (Dorian 1994), the role of adolescents and adults (re)discovering and learning the minority language (Nelde 1982; Morris 2000; Littlebear 1999) is outweighed by literature that above all highlights a direct link between the maintenance of a native speaker community and language survival.

Only in recent years, a critical appraisal of such a view on minority language maintenance and revitalization has gained ground. Fishman's (1991) influential Graded Intergenerational Disruption Scale (GIDS) that is both meant to analyze language shift processes as well as to serve as a tool that helps at developing strategies to reverse such processes has been repeatedly criticized. One major critique concerns its limited focus on the role of domains outside the home-family-neighbourhood in intergenerational minority language transmission. The sociologist Glyn Williams (2007: 163), for example, criticizes Fishman's view on language shift reversal for its "failure to relate the role of language in the economy, its relevance for labour market segmentation and social mobility, and how this can afford the necessary motivation for family and community use and the insistence on educational incorporation" (see Jernudd and Nekvapil 2012 for a summary of critical approaches). Encouraged by the work of Nelde et al. (1996), Williams (2000), Grin et al. (2002) and others, language maintenance and revitalization efforts have come to be seen as requiring a total package of mutually enriching and complementary measures that take a variety of language user and usage profiles into account. Such views on maintenance and revitalization have the advantage of being much closer to the reality of many minority language communities in Europe and beyond. In many settings, language policy and planning initiatives have succeeded in extending the use of the minority language beyond the home domain into new social spaces, particularly through enhanced provision for minority languages in the media, school curricula, and other public and semi-public domains. LPP initiatives have thus 
contributed to an increase of the number of second language learners and users (Gruffudd and Morris 2010). Such learners and users have caught the attention of sociolinguists and linguistic anthropologists that at the turn of the millennium came out of the shadows of macro-sociolinguistic research.

Rather than focusing on the community as a whole (with the inherent risk of presenting it as homogeneous), recent work in sociolinguistics has come to emphasize the linguistic repertoire of the individual speaker or the speaker as a member of a community of practice (Busch 2012). Rather than putting the 'prototypical native minority language speaker' at center stage, the focus has shifted towards speakers (or groups of speakers) who did not inherit the minority language as a native language, yet for a variety of idiosyncratic reasons made the choice to start using the language as part of their linguistic repertoire, in a sense adopted the language, and at least partly identify themselves as 'members by choice' of the minority language community. As a consequence, new speakers and their linguistic practices do have an impact on the corpus, the status, the prestige as well as the acquisition of the minority language and almost force other members of the minority language community to take their way of using the language and their opinion on the fate of the minority language into account.

In minority language contexts, speakers with the profile described above, have been given specific labels such as neofalantes (used in the Galician context to describe speakers who acquired Galician outside of the home, cf. Ramallo 2013), euskaldunberri (a folk term used in the Basque Country to refer to 'new speaker' of Basque, see Urla 2012), neo-Bretons (to describe second language speakers of Breton, see Le Nevez 2006; Hornsby 2008), new Catalans (used by Woolard 1989 to refer to second language speakers of Catalan who were in the process of actively using the language and engaging in bilingual behavior), or gaeilgeoir (which literally translates as 'Irish speaker', yet is used more specifically for Irish language enthousiasts in a broad sense rather than for those speakers of Irish who were brought up with the language, see Zenker 2013 on Northern Ireland). While Robert (2009) made use of the 'new speaker' label to refer to individuals who acquired Welsh in the context of Welsh medium education, its use as a more general label gained momentum with the formation of a research network in 2013 under the European Framework in Science and Technology (see www.nspk.org.uk). That network provided a space that allowed for the development of connections between regional minority language and other perspectives on 'new speakerness' in the context of migration and transnational mobility (see O'Rourke et al. 2018). In this paper, we present an elaboration of the theoretical discussions held within the language policy thematic group of the network; before delving into details, however, we find it necessary to discuss briefly the more traditional theoretical frameworks on language policy, which have preceded and informed 'new speaker' debates.

\section{'New speaker' research in traditional language policy scholarship}

While language policy and planning as human activities have been going on for centuries (see Labrie 1996), the more systematic development of language policy and planning (see Hornberger 2006 on the use of the LPP designation) as a subdiscipline 
of linguistics took off in the 1950s and the 1960s and ran parallel to the development of much of the different sorts of hyphenated linguistics. When trying to roughly phase the field of LPP starting in the 1960s, one can-as already noted elsewhere (Darquennes 2013: 14)_distinguish three broad phases: In a first phase that started in the 1960s and ran until the late 1970s the basic LPP terminology was developed, LPP frameworks were elaborated and scholars reflected on the contribution of sociolinguistics and the sociology of language to finding solutions to societal language problems (Fishman 1972: 186). When the second phase of LPP took off around the early 1980s, LPP concepts were further refined. Specific for the second phase was, however, above all the critical discussion of the way in which LPP had been approached during the first phase. Not only the rational approaches to LPP were criticized. Attention was also given to the limitations and the negative effects of LPP, as well as the ideological nature of LPP (see e.g. Ricento 2000, 2009; Tollefson 2002). Towards the turn of the millennium, a third and still ongoing phase emerged. Characteristic of this phase is that more systematic attention is now paid to "the variety of day-to-day practices and techniques (governmentality) that effectuate policies (stated or unstated) and the ideologies (often widely accepted as common-sense, and hence, non-ideological) which inform particular social outlooks on a range of issues involving language" (Ricento 2009: 224).

Already in the early days of sociolinguistics and most certainly in the European context language minorities were at the heart of LPP research. Researchers not only focused on the way in which nation-states treated minority language communities policy-wise. They also reflected on (mostly top-down) strategies that could or should be developed for or by the autochthonous minority language communities themselves to halt or reverse language shift processes. Against the background of what has been described in the previous section, it comes as no surprise that LPP literature initially focused mainly on the development of measures aimed at protecting and promoting the minority language for and by the 'prototypical' representatives of an autochthonous language minority. A gradual shift in focus took place in the 1990s when not only the importance of the reproduction (i.e. intergenerational minority language transmission) but also of the production of the minority language (i.e. its promotion through language learning and community initiatives outside the family) started to be more prominently emphasized (Nelde et al. 1996).

Next to that, some recent trends in sociolinguistics helped to shift the attention away from the community and top-down policy level to the language use and language management practices of the individual language user. These trends include the rise of literature on the formation, the articulation and the entextualization of language ideologies and their influence on language policy and planning (Blommaert 1999), the expanded interest for the study of linguistic repertoires along the lines of Gumperz (1964), the development of a sociolinguistics of speakers' choices (Coulmas 2003) and a sociolinguistics of globalization (Coupland 2003) that prefer ethnographic and anthropological approaches to linguistic reality over big data (see also Coupland 2016). Especially since the turn of the millennium an increasing number of research projects question essentializing views of language and speakerhood. It is in this changing climate that research on 'new speaker' emerged and started to add to LPP literature of which it had itself not really been a central topic 
before. Next, we explore in more detail how this shifting focus in language policy research connects with 'new speaker' scholarly discussions.

\section{Language policy themes in 'new speaker' research}

From a language policy perspective, 'new speaker' research draws heavily on the idea that, as Pujolar and Puigdevall (2015: 171) have put it, a "speech community can no longer be portrayed as made up exclusively of those who have 'inherited' the language in the conventional way and deserve the specific forms of protection or legitimization associated with revitalization policies". Because of that, there is an urgent need to "query how policies address and affect those who have 'adopted' the language in other ways too". As part of more general questions regarding the form and functions of 'new speakers' and their repertoires, research on 'new speaker' increasingly deals with these queries in a variety of ways. Rather than trying to squeeze outcomes of 'new speaker' research into existing frameworks in LPP research-such as the distinction between (overlapping) activities or actions concentrating on the corpus, the status, the prestige and/or the acquisition of a language or a language variety (see the work of Haugen 1987; Kloss 1969; Cooper 1989; and Haarmann 1990) - the LPP content of research on 'new speaker' can be summarized along the lines of three interrelated LPP themes: (1) beliefs and ideas about language and the legitimate speakers of minority languages that underlie existing language policies; (2) the management of minority language variation; and (3) individual speakers' practices and the way in which they are governed and influence the practices of other speakers.

The starting point for research that is mainly related to the first theme is that language policy is invariably based on linguistic ideologies, i.e. on images of societally desirable forms of language use and the ideal social linguistic landscape that are themselves part of and/or derived from larger often historically rooted socio-political ideologies (cf. Blommaert 2006: 244). As a consequence, the analysis of language policy decisions or statements reveals ideological orientations in relation to assumptions about language in general and/or a specific language use. In autochthonous minority settings, language policies were and to a great extent still are rooted in beliefs and ideas about language that celebrate the ideal of the authentic native speaker who is linked to a bounded, homogeneous speech community of members who share a particular historical past and a particular territorial space (e.g. Makoni and Pennycook 2007 on the link between language and territory in Western linguistic and cultural ideologies). The authentic native speaker uses an authentic variety which — according to Woolard (2008: 304) — can be characterized as a variety that "must be very much 'from somewhere' in speakers' consciousness" and whose "meaning is profoundly local". If it is so that "such social and territorial roots are not discernable, a linguistic variety lacks value in the system" (Woolard 2008: 304).

Woolard (2008) bases her assumptions on observations in Catalonia, yet similar observations with regard to the symbolic value attributed to authentic varieties in minority language settings have been made elsewhere in minority language settings in Europe (cf. Costa 2015; Hornsby 2015; Jaffe 2015; O’Rourke and Walsh 2015; 
Ortega et al. 2015). Obviously, the claim on the authentic variety of the minority language by (some of) the native speakers can —as Woolard (2008: 315) arguesimpede the acquisition and use of a minority language as a second or additional language by members of the larger population who may value their use of the minority language as not being or sounding 'natural', 'authentic' or 'pure' enough in comparison to the native speakers' use of the minority language. The fact that traditional native speakers - as, for example, Urla (2012) and O'Rourke and Ramallo (2013) have noticed-sometimes instrumentalize the use of an 'authentic' variety to establish a social closure that functions as a control mechanism for in-group membership, can lead to frustration among those who-for different reasons, including reasons of integration as required by the government-are in the process of learning the language. It might even discourage them from using it altogether (McEwan-Fujita 2010; O'Rourke 2011). From a purely rational point of view, one could be tempted to consider the promotion of a standardized form of the minority language as an ideal way-out to resolve tensions around the valorization of certain more authentic or pure varieties of a minority language as opposed to other varieties. However, LPP research on the management of minority language variation (the second theme identified above) shows that this is not necessarily the case.

In autochthonous language minority settings, it often seems that LPP efforts concentrate a lot more on minority language standardization than on the celebration or the promotion of minority language variation. Standardization is often presented as an attempt that should help to demonstrate that the minority language is on a par with the surrounding dominant majority language that is more commonly associated with the public sphere (see Darquennes and Vandenbussche 2015: 11; Urla 1993: 246). Advocates of minority language standardization tend to underline not only the symbolic role of a standardized variety but also its contribution to the production of uniform administrative documents, legal texts, terminological databases and books, as well as to the use of the standardized variety in educational settings (see also Eloy 2014: 8-9). Others point above all to the fact that the promotion of a standardized variety has the potential of driving active users of the minority language away from the use of their 'non-standard', everyday variety that contributes a lot more to the vitality of the minority language than the standardized variety itself. The fact that standardization of the minority language paves the way to the adoption of a social hierarchy similar to the one that marks the varieties of the surrounding majority language can lead both to a disempowerment of vernacular forms as well as to a societal stigmatization of the standardized as well as the non-standardized varieties of the minority language: whereas the standardized variety most certainly from the point of view of those who are in favour of top-down standardization efforts has more 'prestige' than the non-standard varieties, the prestige of the non-standard varieties (as more 'authentic' and 'pure' varieties) might in reality be higher than the standardized variety in specific community settings. That poses a particular challenge to 'new speaker'. Exposed to the standardized variety in educational settings, they soon have to experience that the standardized variety that is used in an educational context and the idiosyncratic use that they make of it do not correspond to the traditional dialectal varieties to which 'new speaker' often aspire. As Ramallo and Rei Doval (2015: 75) put it, with reference to the case of Galician, the attribution 
of different values to different varieties leads to tensions and unexpected practices, such as the fact that traditional speakers of Galician switch to Spanish when interacting with 'new speaker'. The reasons for this are manifold: they either do this because they think that the variety used by 'new speaker' is better, more accurate, or more correct than their own, or because they think that 'new speaker' make use of inauthentic or artificial language that is very far from their own. As a matter of fact, Ramallo and Rei Doval (2015: 75) argue that "the lack of authenticity is something that 'new speaker' have accepted". The 'new speaker' themselves "normally consider their way of speaking as 'imperfect', far from 'traditional language' and 'considerably improvable",.

The thick descriptions that are offered in the literature on language standardization attempts and debates in 'new speaker' settings (Costa 2016) not only show the existence of quite some conflict (potential) between the different sorts of speakers concerning the authenticity and purity (one could also say: modernity and hybridity) of the minority language varieties that are in use. They also show that the groups of traditional and 'new speaker' are all but homogeneous in themselves. An absolute correspondence between pure/authentic varieties and traditional speakers, on the one hand, and more hybrid varieties and 'new speaker', on the other hand, cannot be taken for granted. On top of that, the identification of individuals with and/or their beliefs and ideas about certain varieties of a minority language is (sometimes) subject to change over time depending on the life trajectories of each individual (Ó hIfernáin 2015). Indeed, important changes in one's living conditions (moving places, changes during the school cycle, entering the job market, establishing a family, etc.) represent key moments in one's life that may activate the use of particular languages available in one's repertoire (on that note, see the concept of linguistic 'mudes' as proposed by Pujolar and Puigdevall 2015). What one is confronted with is a rather complex and dynamic web of different sorts of practices related to different sorts of varieties linked to different sorts of beliefs and ideas about language. The ethnographic study of these individual speakers' practices and the way in which they are governed and influence the practices of other speakers constitutes a third language policy theme in 'new speaker' research.

Following recent tendencies in LPP research (Johnson 2013), a part of the more recent 'new speaker' research has come to prioritize the understanding of how official language policies that have been given shape at the national or regional governmental level are interpreted and negotiated 'on the ground' by different social actors, including non-native speakers of a given national or regional language. At least partly inspired by Ricento (2009: 224) and Urla (2012), research on 'new speaker' has come to make use of Foucault's (1980) notion of governmentality to describe the complementary use of different language varieties as part of one's language repertoire in different sorts of - above all private and semi-public_-social spaces.

Foucault's (1980) concept of governmentality relies on the idea that power governs all aspects of social life, individually or collectively, and that it provides a rationalization of how people should behave in society (Inda 2005). In doing so, it diverts attention away from a focus that limits itself to the analysis of official language policies and language ideologies. All aspects of social life are considered to be subject to certain modalities of power and governance. Governmentality thus not 
only entails the way in which a national, regional or local government tries to mould the linguistic behaviour of citizens by means of a variety of organizational techniques and practices within the social spaces controlled by that very government. It also refers to how people interpret existing policy expectations and the power structures from which they emerge. Research reveals that top-down language policy initiatives in minority language settings contribute in a positive way to the institutionalized production of the minority language in that they help to shape a context in which speakers learn the minority language in educational settings and develop a capacity to start using it in everyday life. When classes are over, however, the 'new speaker' soon find out that it is hardly straightforward to put their (limited) competences into practice because they are not yet part of a larger social network in which the minority language is actively used (Vila 1996). Sometimes their counterparts switch to the use of another language to facilitate communication. Sometimes the 'new speaker' idiosyncratic use of the minority language is not considered as pure or legitimate in a certain setting. However, that does not inhibit 'new speaker' from developing day-to-day practices and techniques (Ricento 2009) that enable them to actively use the newly acquired minority language in private or semi-public settings. 'New speakers' who are the product of top-down acquisition policy often develop into language policy agents themselves who, through their own active use of the language and their engagement in reflective sociolinguistic practices, challenge existing language-related power structures 'on the ground' (O'Rourke and Ramallo 2011). 'New speaker' scholarship shows that the language practices and ideologies that emerge in a given context highlight the potential discursive tensions present among different collectives in that context, illustrating processes of adaptation or resistance to power domination (see Urla 2012 and Augustyniak and Higham in this volume for a discussion of the Basque context along these lines).

To date, 'new speaker' research dealing with the three themes identified above has been mostly concerned with discussing questions of linguistic legitimacy, authenticity, and authority, drawing in many cases on Bourdieu's (1991) well known account of the power struggles that these concepts encapsulate. By re-casting the focus on the speaker and his or her individual decisions in terms of language practices and ideologies, 'new speaker' research effectively connects with critical language policy research, which tries to understand "how individuals and groups are coerced into language acquisition, language loss, and patterns of language use by powerful external forces that control the processes of language policymaking" (Tollefson 2015: 141). 'New speaker' research sheds light into how power operates in structures of domination or conflict, and how human agency plays a role in coconstructing such frameworks. In illuminating processes of resistance or adaptation to given language regimes it fruitfully adds to what Pakir (1994) has called 'invisible language planning', or to Baldauf's (1993) notion of 'unplanned language planning'. However, beyond rich and thick ethnographic studies, 'new speaker' research has not yet explicitly engaged with discussions at the level of language policy development, i.e. the more institutional side of policy creation. If 'new speaker' research wants to play a role in "shaping the processes of language intervention" (O'Rourke et al. 2015: 16) in the way that (parts of) linguistics and its related strands have done so in the past, it would have to concentrate on the way in which day-to-day 
practices and techniques on the part of 'new speakers' so to speak 'move up the LPP ladder', are then translated into top-down LPP initiatives, how and with what goals and outcomes (see Williams, this issue). In short, 'new speaker' research is certainly well situated to dig deeper in the analysis of the language policy cycle (Canagarajah 2006) and provide a better understanding of the ways in which different levels of policy development, interpretation, appropriation, and resistance/adaptation work. We elaborate more on the latter in the following section of the paper.

\section{'New speaker' and the discursive turn in language policy research}

Recent developments in the field of language policy have emphasized precisely the discursive and poly-level nature of policymaking (e.g. Barakos and Unger 2016; Halonen et al. 2015). One particular strand of language policy research that has adopted this critical angle and has become increasingly more solidified is the ethnography of language policy (Johnson 2009, 2013; Hornberger and Johnson 2007; McCarty 2011). The ethnography of language policy (henceforth: ELP) represents an epistemological and methodological renovated perspective on language policy analysis. The main idea is to explicitly incorporate an ethnographic perspective to the study of language policy processes and contexts. This, however, does not mean that one just adds some ethnographic analysis into an account of LPP processes. ELP rather tries to incorporate the epistemologies and ontologies of ethnography into language policy analyses by viewing language as inherently socially and ideologically fraught, and by incorporating a historical (i.e. diachronic) view on LPP processes (Blommaert 2013). The basic tenet of ELP is to examine "agents, contexts, and processes across the multiple layers of language policy creation, interpretation, and appropriation" (Johnson 2013: 44). In this way, ELP's main thrust is to offer a method to resolve the tension between critical theory's analyses of how power operates at a macro level and the agentive creativity of individual speakers. In short, the aim is to bridge the perennial gap in scholarship between the macro- and micro-level dimensions of social life (Hult 2010).

Through unpacking the social meanings of language policy, ELP helps to make connections between the different layers of language policy-making (individual, institutional, national, supranational), and it examines those connections ethnographically (Hornberger and Johnson 2007). More specifically, according to McCarty (2015: 81): "For ethnographers of LPP, this entails a view of policy as a situated sociocultural process: the practices, ideologies, attitudes, and mechanisms that influence people's language choices in pervasive everyday ways." Thus, from the theoretical point of view, ELP has the merit of illustrating the power of linguistic ideologies in a given language policy setting. By carefully tracing how discourses circulate from layer to layer in the LPP cycle (Canagarajah 2006), researchers can demonstrate the ways in which macro level discourses on language policies are created and how they are then interpreted and appropriated or resisted at the micro level. Utilizing ethnographic tools, scholars are able to detect such circulation of discourses and to examine them critically. In addition to that, ELP has the potential not 
only to critically describe and analyze a particular language policy setting, but also to empower practitioners 'on the ground' in order to bring about meaningful social change and possibly redress power inequalities (Johnson 2009; McCarty 2015).

The ethnography of language policy, therefore, represents one well defined framework within the discursive turn in language policy studies. In this type of LPP research, language policy is often seen as social action taking place at the intersection of individuals' trajectories, societal discourses, and interactional orders (see Hult 2015). With its focus on the speaker and the social consequences of his or her crossing linguistic and cultural boundaries, 'new speaker' research seems well situated to add fruitfully to this renovated strand of language policy scholarship. Indeed, the policy interpretation, appropriation and/or resistance suggested in ELP research is clear in most of the studies on 'new speakers'. For instance, O'Rourke and Ramallo $(2013,2015)$ analyze how groups of 'new speaker' of Galician negotiate their legitimacy as speakers of the language vis-à-vis traditional speakers. Their stance as middle-class, young, urban-based, and politically motivated individuals makes them interpret language policies in Galicia in a way that shows resistance to hegemonic, centralizing ideologies of the Spanish state (see also O'Rourke and Nandi, this volume). At the same time, their adoption of Galician creates resistance or friction among both traditional speakers of the language and speakers of Spanish in Galicia, who might also question their stance. This is also often the case in the context of Basque (e.g. Ortega et al. 2015), Irish (O'Rourke 2011) and most of the linguistic minorities that have been analyzed under the lens of the 'new speaker' framework. That said, it may be possible to argue that both ELP and 'new speaker' research may encounter similar kinds of challenges, from which we can highlight at least three.

First of all, it seems to be the case that not infrequently both ELP and 'new speaker' research (whether it focuses on minority language communities or not) gravitate around educational contexts (e.g. Costa 2015; Jaffe 2015; see also Augustyniak and Higham, Spotti et al., and Soler and Marten, this issue). Indeed, the 'school bias' of sociolinguistic research (i.e. relying on educational settings to obtain data and build analyses) has been acknowledged for some time in the field (cf. Heller 2007). In the case of 'new speaker' work, this is perhaps less surprising given that schools are probably the most important institution when creating 'new speaker', enabling people of different linguistic backgrounds to learn and activate (then or later in their lives) a variety different than their home language. With this in mind, it may be possible to argue that both the ELP framework and the "new speaker' lens should be expanded to include a greater variety of other contexts. Johnson and Ricento (2013) do mention that recent work in language policy has seen a significant increase in the different settings that are covered with an ethnographic orientation, including families, religious organizations, call centres, medical and health care settings, etc. Our suggestion is that the 'new speaker' perspective may provide fruitful avenues in order to explore possibilities for extending ethnographic language policy analyses that go beyond educational settings and, thus, to expand/develop along the lines set out, for example, in work on football fans (Del Percio 2015) and transnational workplaces (see Kraft this volume). The need to get away from a focus on settings that are traditionally subject to institutional language 
policy arrangements as well as from a primary focus on the way in which institutional discourse is handled at different policy layers is something that is echoed in Pérez-Milans' (2018) critique of ELP.

Focusing on the ELP framework, Pérez-Milans (2018) offers a reasoned argument in the direction of suggesting ELP scholarship to align itself more closely to linguistic-anthropological work by focusing on the performative function of language (rather than its denotational value) and by examining speakers' trajectories of socialization more closely. Pérez-Milans argues that there is a tendency in ELP work (and, we would add, in some 'new speaker' research as well), to overly rely on speakers' explicit talk about institutionally formulated language policies, and to portray speakers as mere participants in a given pre-determined context. Crucially enough, paying attention to the performative nature of language and analyzing closely speakers' socialization trajectories are not simply "methodological warrants for describing or documenting processes of policy implementation/appropriation in specific (local and institutional) settings. They also offer us routes to further engage with ongoing sociological discussions on language, culture, and socioeconomic change" (Pérez-Milans 2018: 135-136). 'New speaker' work is not immune to overlooking the performative function of language and to undermine speakers' socialization trajectories. However, by placing the speaker at the centre of attention, 'new speaker' research is well situated to bring ELP work closer to linguistic-anthropological tenets, as Pérez-Milans suggests. Proceeding in such a way can indeed help uncover deeper level issues of linguistic and economic inequalities, a goal that deserves being pursued however difficult (theoretical and methodological) the challenges ahead may be.

While putting the speaker at central stage is most certainly a valuable goal as such, care needs to be taken to not only focus on speakers' performances and/or the way in which they interpret, appropriate or resist top-down language policies. Attention also needs to be given to the influence that policy interpretations and appropriations at the ground level have on the shape of the institutional arrangements. Until now, it seems that attention has above all been given in ELP as well as in 'new speaker' research to the way in which official language policies have been interpreted, appropriated or resisted at the lower levels, yet not so much on the way in which the interpretation, appropriation or resistance of official language policy initiatives makes its way to and/or is itself perceived and dealt with at the higher levels of the top-down continuum. While we certainly do agree with the point of view that 'top-down' and 'bottom-up' are relative concepts in LPP and that focussing only at the top or the bottom does not help to shed light on the complexity of the various LPP layers (Johnson 2013: 108), we do think that one way of highlighting that very complexity could be to approach the 'top' and the 'bottom' not as parts of a clearcut dichotomy but as parts of a continuum, and to navigate the top-down-continuum in both directions in a systematic way. Navigating the top-down-bottom-up continuum-most certainly when linked to a well-contextualized study of the discursive practices of the many actors involved in the process-will allow for a better understanding of the actual interaction between the multiple policy layers. It might not only help to shed light on ideas and beliefs about language (and language use) but also about the practical constraints that influence official language policies. Such an 
exercise comes closer to scanning (rather than peeling) the LPP onion which allows for a more 'holistic' look at the intersections between the layers and the multidirectional flow of discourses between different policy levels and the multiple actors that inhabit and sometimes circulate between the different policy levels and at times perform different roles at different stages of the entire policy process.

\section{Concluding remarks}

Regardless of the context, language policy issues often lead to power struggles, played out in the implicit or explicit negotiation of what linguistic resources and practices are valorized by whom and under which conditions. For example, in autochthonous language minority contexts, one of the side effects of officially formulated policies that has been observed across different cases in Europe is the fact that a (central) part of the language revitalization agendas of some key stakeholders involves the active incorporation of non-traditional speakers of the language, who may lay claims to ownership of the language and be in search of equally legitimate voices within the community of speakers (e.g. O'Rourke and Ramallo 2015). Furthering this line of inquiry, we detect a need to continue examining a range of different contexts with a specific focus on how language policy matters are dealt with by different actors at different LPP levels, i.e. by speakers 'on the ground' as well as by language policy and planning officers and other agents in managerial positions. In order to address and capture the complex interaction of multiple layers of society in the co-construction of language policy frameworks it might be useful to follow Halonen and collaborators' (2015: 3) take on language policy, noting that "politics and policies are essentially multi-sited by nature, taking place, being constructed, contested and reproduced on different horizontally and vertically linked levels simultaneously and in different times and places". An ethnographic approach to LPP issues seems to be well suited to the task at hand, especially if, as Pérez-Milans (2018) rightly notes, careful attention is paid to the performative function of language, at speakers' socialization trajectories, and at the struggle for access and control over key language resources at the different levels of the policy process.

Acknowledgements Research leading to this article has benefitted from ongoing discussions on the "new speaker' theme as part of the EU COST Action IS1306 network entitled 'New speakers in a multilingual Europe: Opportunities and challenges'.

Open Access This article is distributed under the terms of the Creative Commons Attribution 4.0 International License (http://creativecommons.org/licenses/by/4.0/), which permits unrestricted use, distribution, and reproduction in any medium, provided you give appropriate credit to the original author(s) and the source, provide a link to the Creative Commons license, and indicate if changes were made.

\section{References}

Allardt, E. (1992). Qu'est-ce qu'une minorité linguistique? In H. Giordan (Ed.), Les minorités en Europe. Droits linguistiques et Droits de l'Homme (pp. 45-54). Paris: Editions Kimé. 
Baldauf, R. (1993). Unplanned language policy and planning. Annual Review of Applied Linguistics, 14, 82-89.

Barakos, E., \& Unger, J. (2016). Discursive approaches to language policy. Basingstoke: Palgrave Macmillan.

Blommaert, J. (1999). The debate is open. In J. Blommaert (Ed.), Language ideological debates (pp. $1-38)$. Berlin, New York: Mouton de Gruyter.

Blommaert, J. (2006). Language policy and national identity. In T. Ricento (Ed.), An introduction to language policy: Theory and method (pp. 238-254). Oxford: Wiley Blackwell.

Blommaert, J. (2010). The sociolinguistics of globalization. New York: Cambridge University Press.

Blommaert, J. (2013). Policy, policing and the ecology of social norms: Ethnographic monitoring revisited. International Journal of the Sociology of Language, 219, 123-140.

Blommaert, J., \& Backus, A. (2011). Repertoires revisited: 'Knowing language' in superdiversity. Urban Language and Literacies, 67, 1-26.

Blommaert, J., Kelly-Holmes, H., Lane, P., Leppänen, S., Moriarty, M., Pietikäinen, S., et al. (2009). Media, multilingualism, and language policing: An introduction. Language Policy, 8(3), 203-207.

Bourdieu, P. (1991). Language and symbolic power. Cambridge: Polity Press.

Busch, B. (2012). The linguistic repertoire revisited. Applied Linguistics, 33(5), 503-523.

Busch, B. (2015). Expanding the notion of the linguistic repertoire: On the concept of Spracherleben The lived experience of language. Applied Linguistics, first published online July 232015.

Canagarajah, S. (2006). Ethnographic methods in language policy. In T. Ricento (Ed.), An introduction to language policy: Theory and method (pp. 153-169). Oxford: Wiley Blackwell.

Cooper, R. (1989). Language planning and social change. Cambridge: Cambridge University Press.

Costa, J. (2015). New speakers, new language: On being a legitimate speaker of a minority language in Provence. International Journal of the Sociology of Language, 231, 127-145.

Costa, J. (2016). Revitalising language in Provence: A critical approach. Transactions of the Philological Society, 114, 1-184.

Coulmas, F. (2003). SociolinguisticsL The study of speakers' choices. Cambridge: Cambridge University Press.

Coupland, N. (2003). Sociolinguistics and globalisation. Journal of Sociolinguistics, 7(4), 465-472.

Coupland, N. (Ed.). (2016). Sociolinguistics: Theoretical debates. Cambridge: Cambridge University Press.

Darquennes, J. (2013). Current issues in LPP research and their impact on society. AILA Review, 26, $11-23$.

Darquennes, J. (2014). Macrosociolinguïstisch onderzoek naar historische taalminderheden in tijden van globalisering-pleidooi voor een vernieuwing van binnenuit [Macro-sociolinguistic research on historical language minorities in times of globalization - a plea for a change from within]. Us Wurk, 63(1-2), 73-92.

Darquennes, J., \& Vandenbussche, W. (2015). The standardisation of minority languages: Introductory remarks. In J. Darquennes \& W. Vandenbussche (Eds.), The standardisation of minority languages (Sociolinguistica 29) (pp. 1-15). Berlin: de Gruyter.

Davies, A. (2003). The native speaker: Myth and reality. Clevedon: Multilingual Matters.

Del Percio, A. (2015). New speakers on lost ground in the football stadium. Applied Linguistics Review, 6(2), 261-280.

Doerr, N. M. (Ed.). (2009). The native speaker concept: Ethnographic investigations of native speaker effects. Berlin, New York: Mouton de Gruyter.

Dorian, N. (1994). Purism versus compromise in language revitalisation and language revival. Language in Society, 23(4), 479-494.

Eloy, J. M. (2014). Standardisation et vitalité des langues de France. Paris: L'Harmattan.

Fishman, J. (1972). Language in sociocultural change. Stanford: Stanford University Press.

Fishman, J. (1991). Reversing language shift. Clevedon: Multilingual Matters.

Foucault, M. (1980). Power/knowledge: Selected interviews and other writings. New York: Pantheon Books.

Gal, S. (1979). Language shift: Social determinants of linguistic change in bilingual Austria. New York: Academic Press.

Grin, F., et al. (2002). SMiLE: Support for Minority Languages in Europe. Brussels: European Commission. 
Gruffudd, H. \& Morris, S. (2010). Canolfannau Cymraeg and social networks of adult learners of Welsh: Efforts to reverse language shift in comparatively non-Welsh-speaking communities. Swansea: Academi Hywel Teifi (https://www.swansea.ac.uk/media/Full\%20Report.pdf)

Gumperz, J. (1964). Linguistic and social interaction in two communities. American Anthropologist, $66(6), 137-153$.

Haarmann, H. (1990). Language planning in the light of a general theory of language: A methodological framework. International Journal of the Sociology of Language, 86, 103-126.

Halonen, M., Ihalainen, P., \& Saarinen, T. (Eds.). (2015). Language policies in Finland and Sweden: Interdisciplinary and multi-sited comparisons. Bristol: Multilingual Matters.

Haugen, E. (1987). Language planning. In U. Ammon, et al. (Eds.), Sociolinguistics (Vol. 1, pp. 626637). Berlin, New York: de Gruyter.

Heller, M. (Ed.). (2007). Bilingualism: A social approach. Basingstoke: Palgrave Macmillan.

Hornberger, N. (2006). Frameworks and models in language policy and planning. In T. Ricento (Ed.), An introduction to language policy: Theory and method (pp. 24-41). Oxford: Wiley Blackwell.

Hornberger, N., \& Johnson, D. (2007). Slicing the onion ethnographically: Layers and spaces in multilingual language education policy and practice. TESOL Quarterly, 41(3), 509-532.

Hornsby, M. (2008). The incongruence of the Breton linguistic landscape for young speakers of Breton. Journal of Multilingual and Multicultural Development, 29(2), 127-138.

Hornsby, M. (2015). The "new" and "traditional" speaker dichotomy: Bridging the gap. International Journal of the Sociology of Language, 231, 107-125.

Hult, F. (2010). Analysis of language policy discourses across the scales of space and time. International Journal of the Sociology of Language, 202, 7-24.

Hymes, D. (1972). On communicative competence. In J. B. Pride \& J. Holmes (Eds.), Sociolinguistics. Selected readings (pp. 269-293). Harmondsworth: Penguin.

Inda, J. X. (Ed.). (2005). Anthropologies of modernity: Foucault, governmentality, and life politics. Oxford: Wiley Blackwell.

Jaffe, A. (2015). Defining the new speaker: Theoretical perspectives and learner trajectories. International Journal of the Sociology of Language, 231, 21-44.

Jernudd, B., \& Nekvapil, J. (2012). History of the field: A sketch. In B. Spolsky (Ed.), The Cambridge handbook of language policy (pp. 16-36). Cambridge: Cambridge University Press.

Johnson, D. (2009). Ethnography of language policy. Language Policy, 8(2), 139-159.

Johnson, D. (2013). Language policy. Basingstoke: Palgrave Macmillan.

Johnson, D., \& Ricento, T. (2013). Conceptual and theoretical perspectives in language planning and policy: Situating the ethnography of language policy. International Journal of the Sociology of Language, 219, 7-21.

Kloss, H. (1969). Research possibilities on group bilingualism. Québec: Université Laval, Centre International de Recherches sur le Bilinguisme.

Labrie, N. (1996). Politique linguistique. In H. Goebl, P. H. Nelde, W. Wölck, \& Z. Stary (Eds.), Contact linguistics (Vol. 1, pp. 826-833). Berlin: de Gruyter.

Le Nevez, A. (2006). Language diversity and linguistic identity in Brittany: a critical analysis of the changing practice of Breton. Ph.D. thesis. Sydney: University of Technology Sydney.

Littlebear, R. (1999). Some rare and radical ideas for keeping indigenous languages. In J. Reyhner, et al. (Eds.), Revitalizing Indigenous Languages (pp. 1-5). Flagstaff, AZ: Northern Arizona University.

Makoni, S., \& Pennycook, A. (2007). Disinventing and reconstructing languages. In S. Makoni \& A. Pennycook (Eds.), Disinventing and reconstructing languages (pp. 1-41). Clevedon: Multilingual Matters.

May, S. (2001). Language and minority rights: Ethnicity, nationalism and the politics of language. New York and London: Routledge.

McCarty, T. (Ed.). (2011). Ethnography and language policy. New York, London: Routledge.

McCarty, T. (2015). Ethnography in language planning and policy research. In F. Hult \& D. Johnson (Eds.), Research methods in language policy and planning: A practical guide (pp. 81-93). Oxford: Wiley Blackwell.

McEwan-Fujita, E. (2010). Ideology, affect, and socialization in language shift and revitalization: The experiences of adults learning Gaelic in the Western Isles of Scotland. Language in Society, 39, 27-64.

Morris, S. (2000). Adult education, language revival and language planning. In C. Williams (Ed.), Language revitalization: Policy and planning in Wales (pp. 208-220). Cardiff: University of Wales Press. 
Moseley, C. (Ed.). (2010). Atlas of the Worlds' languages in danger. Paris: UNESCO Publishing.

Nelde, P. (1982). Sprachökologische Überlegungen am Beispiel Altbelgiens. Germanistische Mitteilungen, 15, 81-92.

Nelde, P., Strubell, M., \& Williams, G. (1996). Euromosaic. The production and reproduction of the minority language groups in the European Union. Luxembourg: Office for Official Publications of the European Communities.

Ó hIfernáin, T. (2015). Back to the future: Standard and language standards in contemporary Manx. Sociolinguistica, 29, 99-119.

O'Rourke, B. (2011). Whose language is it? Struggles for language ownership in an Irish language classroom. Journal of Language, Identity and Education, 10(3), 327-345.

O'Rourke, B., \& Pujolar, J. (2013). From native speakers to "new speakers": Problematizing nativeness in language revitalization contexts. Histoire Épistemologie Langage, 35(2), 47-67.

O'Rourke, B., \& Pujolar, J. (2015). New speakers and processes of new speakerness across time and space. Applied Linguistics Review, 6(2), 145-150.

O'Rourke, B., Pujolar, J., \& Ramallo, F. (2015). New speakers of minority languages: The challenging opportunity-Foreword. International Journal of the Sociology of Language, 231, 1-20.

O'Rourke, B., \& Ramallo, F. (2011). The native-non-native dichotomy in minority language contexts. Language Problems and Language Planning, 35(2), 139-159.

O'Rourke, B., \& Ramallo, F. (2013). Competing ideologies of linguistic authority amongst new speakers in contemporary Galicia. Language in Society, 42(3), 1-19.

O'Rourke, B., Soler, J., \& Darquennes, J. (2018). New speakers and language policy. In J. Tollefson \& M. Pérez-Milans (Eds.), Oxford handbook of language policy and planning (forthcoming). Oxford: Oxford University Press.

O'Rourke, B., \& Walsh, J. (2015). New speakers of Irish: Shifting boundaries across time and space. International Journal of the Sociology of Language, 231, 63-84.

Ortega, A., Urla, J., Amorrortu, E., Goirigolzarri, J., \& Uranga, B. (2015). Linguistic identity among new speakers of Basque. International Journal of the Sociology of Language, 231, 85-105.

Pakir, A. (1994). Education and invisible language planning: The case of English in Singapore. In T. Kandiah \& J. Kwan-Terry (Eds.), English and language planning: A Southeast Asian contribution (pp. 158-179). Singapore: Times Academic Press. Centre for Advanced Studies, National University of Singapore.

Pennycook, A. (2006). Postmodernims in language policy. In T. Ricento (Ed.), An introduction to language policy: Theory and practice (pp. 60-76). Oxford: Blackwell Publishing.

Pérez-Milans, M. (2018). Metapragmatics in the ethnography of language policy. In J. Tollefson \& M. Pérez-Milans (Eds.), Oxford handbook of language policy and planning (forthcoming). Oxford: Oxford University Press.

Pérez-Milans, M., \& Tollefson, J. (2018). Language policy and planning: Directions for future research. In J. Tollefson \& M. Pérez-Milans (Eds.), Oxford handbook of language policy and planning (forthcoming). Oxford: Oxford University Press.

Pujolar, J., \& Puigdevall, M. (2015). Linguistic mudes: How to become a new speaker in Catalonia. International Journal of the Sociology of Language, 231, 167-187.

Ramallo, F. (2013). Neofalantismo. In E. Gugenberger, H. Monteagudo \& G. Rey-Doval (Eds.), Contacto de linguas, hibridade, cambio: Contextos, procesos e consecuencias (pp. 245-258). Consello da Cultura Galega.

Ramallo, F., \& Rey-Doval, G. (2015). The standardization of Galician. Sociolinguistica, 29, 61-81.

Ricento, T. (2000). Historical and theoretical perspectives in language policy and planning. Journal of Sociolinguistics, 4(2), 196-213.

Ricento, T. (2009). Models and approaches in language policy and planning. In Handbook of language and communication: Diversity and change, M. Hellinger \& A. Pauwels (Eds.), 211-240. Berlin, New York: de Gruyter.

Rindler Schjerve, R. (2006). Regional language minority research in Europe: A call for a change in perspectives. Sociolinguistica, 20, 105-120.

Robert, E. (2009). Accommodating new speakers? An attitudinal investigation of L2 speakers in southeast Wales. International Journal of the Sociology of Language, 195, 93-116.

Tollefson, J. (Ed.). (2002). Language policies in education. Critical issues. Mahwah, NJ: Lawrence Erlbaum Associates.

Tollefson, J. (2015). Historical-structural analysis. In F. Hult \& D. Johnson (Eds.), Research methods in language policy and planning: A practical guide (pp. 140-151). Malden, MA: Wiley. 
Urla, J. (1993). Cultural politics in an age of statistics: Numbers, nations, and the making of Basque identity. American Ethnologist, 20(4), 818-843.

Urla, J. (2012). Reclaiming Basque: Language, nation, and cultural activism. Reno, NV: University of Nevada Press.

Vila, F. X. (1996). When classes are over: Language choice and language contact in bilingual education in Catalonia. Ph.D thesis. Brussels: Vrije Universiteit Brussel.

Williams, C. H. (Ed.). (2000). Language revitalization: Policy and planning in Wales. Cardiff: University of Wales Press.

Williams, G. (2007). Reversing language shift: A sociological visit. In J. Darquennes (Ed.), Contact linguistics and language minorities (Plurilingua XXX) (pp. 161-177). St. Augustin: Asgard.

Woolard, K. A. (1989). Doubletalk: Bilingualism and the politics of ethnicity in Catalonia. Stanford: Stanford University Press.

Woolard, K. A. (2008). Language and identity choice in Catalonia: The interplay of contrasting ideologies of linguistic authority. In K. Süselbeck, U. Mühlschlegel, \& P. Masson (Eds.), Lengua, nación e identidad. La regulación del plurilingüismo en España y América Latina (pp. 303-323). Frankfurt am Main: Vervuert.

Zenker, O. (2013). Irish/ness is all around us: Language revivalism and the culture of ethnic identity in Northern Ireland. New York: Berghahn.

Jeroen Darquennes is Professor of German and General Linguistics at the University of Namur and affiliated researcher at the Mercator European Research Centre on Multilingualism and Language Learning (Leeuwarden, The Netherlands). He is one of the general editors of Sociolinguistica. The international yearbook of European sociolinguistics (De Gruyter). In his research he mainly focuses on issues of language contact, language conflict and language policy and planning in European autochthonous language minority settings.

Josep Soler is Assistant Professor of Applied Linguistics at the Department of English, Stockholm University. Josep has degrees in English Studies and General Linguistics from the University of Barcelona, where he also obtained his $\mathrm{PhD}$ in Linguistics and Communication. His main research interests cover the areas of language policy and linguistic ideologies; he has recently focused on the role of English in the internationalization of higher education, and on the study of practices and ideologies in multilingual families. His research has appeared in Language in Society, Current Issues in Language Planning, Language, Culture and Curriculum, Journal of Multilingual and Multicultural Development, International Journal of Bilingual Education and Bilingualism, and Multilingua. 